\title{
ZNACZENIE LIMITU KREDYTOWEGO I UBEZPIECZENIA KREDYTU KUPIECKIEGO W POLSCE
}

\section{WPROWADZENIE}

Prowadzenie działalności gospodarczej wiąże się z różnymi typami ryzyka. Jednym $\mathrm{z}$ nich jest ryzyko kredytowe, inaczej zwane ryzykiem kredytu kupieckiego. Jego specyfika związana jest z brakiem zapłaty dłużnika za sprzedane $\mathrm{z}$ odroczonym terminem płatności towary bądź usługi. Jego skala i możliwość realizacji uzależnione są od wielu czynników, w tym przede wszystkim sytuacji finansowej kontrahenta, determinującej jego zwyczaje płatnicze. Zagrożenie staje się tym większe, im wyższa niepewność realizowanych przedsięwzięć. Praktyka gospodarcza pozwoliła na wypracowanie rozmaitych form i metod przeciwdziałania wystąpieniu ryzyka oraz jego skutkom. Jedną z nich jest ubezpieczenie należności, czyli transfer ryzyka na podmiot ubezpieczeniowy.

Ochrona ubezpieczeniowa w kredycie kupieckim, ze względu na rozmaite korzyści, które płyną z jej zastosowania, stała się pożądanym narzędziem zabezpieczenia należności przedsiębiorstw, a jej zaangażowanie w Polsce do 2008 r. nieustannie rosło ${ }^{1}$. Pojawiające się wówczas bariery rozwoju ubezpieczenia kredytu handlowego spowodowane były gwałtownym pogorszeniem się sytuacji makroekonomicznej, co skutkowało wzrostem niepewności gospodarczej we wszystkich sektorach gospodarki. Transakcje handlowe pomiędzy przedsiębiorstwami obarczone zostały podwyższonym ryzykiem, co wpłynęło na radykalne obniżenie zaangażowania ubezpieczycieli $\mathrm{w}$ zabezpieczenie należności. Takie podejście nie tylko negatywnie oddziaływało na efektywność przedsiębiorstw dłużnika i wierzyciela, lecz także niekorzystnie wpływało na rozwój ubezpieczenia kredytu kupieckiego ${ }^{2}$. Ukazane okoliczności zmieniły podejście ubezpieczycieli w zakresie udzielania limitów ubezpieczeniowych na transakcje handlowe i ukształtowały nieznany dotąd produkt: ubezpieczenie należności podwyższonego ryzyka.

1 Swiadczyć o tym może wzrost wartości składki przypisanej brutto z tytułu sprzedaży ubezpieczenia kredytu, począwszy od 2003 r., z 204718 tys. PLN do 564988 tys. PLN w 2007 r. Dla przykładu wielkość wskazanego wskaźnika dla Euler Hermes, największego towarzystwa ubezpieczenia kredytu kupieckiego w Polsce, wzrosła z 51862 tys. PLN w 2004 r. do 258487 tys. PLN w 2011 r. Inny ubezpieczyciel - Korporacja Ubezpieczeń Kredytów Eksportowych (KUKE) - już w 2007 r. odnotował 16,4\% spadek wartości wskaźnika do 17670 tys. PLN.

${ }^{2}$ Wartość składki przypisanej brutto spadła w 2008 r. do 488309 tys. PLN i w kolejnych latach, mimo rosnących cen ubezpieczenia, w dalszym ciągu się obniża. 
Copyright of Journal of Law, Economics and Sociology is the property of Faculty of Law and Administration of Adam Mickiewicz University in Poznan and its content may not be copied or emailed to multiple sites or posted to a listserv without the copyright holder's express written permission. However, users may print, download, or email articles for individual use.

Właścicielem praw autorskich do „Ruchu Prawniczego, Ekonomicznego i Socjologicznego” jest Wydział Prawa i Administracji Uniwersytetu im. Adama Mickiewicza w Poznaniu. Zawartość czasopisma nie może być kopiowana, przesyłana do innych stron internetowych bądź zamieszczana na blogach bez pisemnej zgody wydawcy. Niemniej artykuły można drukować, kopiować lub przesyłać w formie elektronicznej na własny użytek. 
Kolejne części artykułu przybliżają istotę kredytu kupieckiego oraz zagrożeń z nim związanych. Wśród rozmaitych instrumentów zabezpieczenia ryzyka braku płatności ze strony dłużnika autor wyróżnia ubezpieczenie należności. Wskazuje na cechy produktu ubezpieczeniowego, jego zalety, jak również wady, wśród których należy wyróżnić trudności w zabezpieczeniu transakcji o podwyższonym ryzyku.

Następnie przedstawiono charakterystykę rzeczywistości gospodarczej po 2008 r., kiedy to gwałtowne pogorszenie koniunktury gospodarczej wpłynęło na zmianę zachowań przedsiębiorców oraz instytucji finansowych, przede wszystkim w zakresie redukcji limitów kredytowych na transakcje handlowe, a w konsekwencji pojawienie się nowych instrumentów zabezpieczenia ryzyka, takich jak ubezpieczenie należności podwyższonego ryzyka w kredycie kupieckim. Scharakteryzowano również omawiane ubezpieczenie i przybliżono jego problematykę.

Podstawa badania kierunku rozwoju ubezpieczenia kredytu kupieckiego i znaczenia limitu kredytowego jest analiza dotychczasowego dorobku naukowego w dziedzinie ubezpieczenia należności. Wykorzystano również własne obserwacje oraz indywidualne wywiady pogłębione (IDI) ${ }^{3} \mathrm{z}$ przedstawicielami przedsiębiorstw oraz towarzystw ubezpieczenia kredytu kupieckiego działających na polskim rynku. Ponadto przeprowadzona analiza porównawcza materiałów źródłowych ubezpieczycieli pozwoliła na ocenę atrakcyjności nowego instrumentu zabezpieczenia ryzyka kredytowego. Wskazała, że efektywność poszczególnych produktów uzależniona jest od stopnia dopasowania oferty do potrzeb klientów.

Niniejsze opracowanie prezentuje istotę przemian ubezpieczenia kredytu kupieckiego w Polsce, które wzmacniają jego znaczenie, a także podkreślają rolę limitu kredytowego na transakcje handlowe pomiędzy przedsiębiorstwami. Hipoteza badawcza pracy wskazuje, że ubezpieczenie należności podwyższonego ryzyka oraz zmiany w zakresie polityki udzielania limitu kredytowego wpływaja na wzrost znaczenia omawianych instrumentów zabezpieczenia ryzyka płatności w Polsce. Wynika to z faktu dobrego dopasowania instrumentów i narzędzi do otaczającej rzeczywistości gospodarczej. Efektywność nowych rozwiązań nabiera szczególnego znaczenia w okresie dekoniunktury, kiedy gwałtownie spada skłonność do ponoszenia ryzyka przez ubezpieczycieli, a w wyniku częstych redukcji limitów kredytowych zmniejsza się zainteresowanie standardowym produktem ubezpieczenia wierzytelności handlowych. Proponowane wówczas zmiany przez ubezpieczycieli mogą spowodować przełamanie pojawiających się barier w zakresie ubezpieczenia należności.

Przeprowadzona analiza potwierdza pozytywną ocenę kierunku przemian procesu ubezpieczenia kredytu kupieckiego i wskazuje na nieustanna aktywność instytucji finansowych w stymulowaniu działalności przedsiębiorstw.

\footnotetext{
${ }^{3}$ Ze względu na aktualność zachodzących procesów zastosowano metody jakościowe, których celem jest wyjaśnienie motywów i postaw przedsiębiorstw oraz podmiotów ubezpieczenia kredytu kupieckiego w zakresie nowych produktów ubezpieczeniowych.
} 


\section{POJECIE ORAZ ISTOTA KREDYTU KUPIECKIEGO}

Kredyt kupiecki jest formą finansowania działalności przedsiębiorstw, polegająca na odroczeniu przez dostawcę płatności za sprzedaż towarów i usług odbiorcy ${ }^{4}$. Leży on u podstaw relacji biznesowej pomiędzy kontrahentami, spośród których jeden jest wierzycielem, a drugi - dłużnikiem w stosunku zobowiązaniowym.

Interdyscyplinarna problematyka kredytu kupieckiego obejmuje nauki o finansach, rachunkowości, prawa i handlu. W dziedzinie finansów skupia uwagę na aspektach efektywności jego wykorzystania oraz roli, jaka pełni w krótkoterminowym finansowaniu przedsiębiorstw. W rachunkowości natomiast kredyt kupiecki ma odzwierciedlenie w bilansie przedsiębiorstwa, w którym występuje po stronie należności ze sprzedaży, jak również po stronie zobowiązań - jako dług powstały w wyniku poniesionych wydatków na zakup towarów i usług. Polskie prawodawstwo sprowadza istotę stosunku zobowiązaniowego do określania wzajemnych praw i obowiązków kontrahentów, wynikających z realizacji sprzedaży z odroczonym terminem płatności ${ }^{5}$. W ujęciu handlowym zaś stymuluje sprzedaż jako narzędzie marketingowej strategii przedsiębiorstw.

Nieodłącznym elementem kredytu kupieckiego jest odroczona płatność. Może mieć ona charakter manipulacyjny lub handlowy ${ }^{6}$. Manipulacyjny charakter kredytu handlowego związany jest $\mathrm{z}$ ograniczeniami organizacyjno-technicznymi, które uniemożliwiają realizację płatności gotówką lub przelewem, ale przed terminem realizacji dostawy. Handlowy charakter odroczonej płatności znajduje uzasadnienie w motywach, którymi kierują się przedsiębiorcy, podejmując decyzję o finansowaniu działalności kredytem kupieckim. Ze względu na różną perspektywę podmiotów uczestniczących w procesie wykorzystania kredytu kupieckiego wyróżnia się motywy dostawcy i odbiorcy ${ }^{7}$. Do pierwszej grupy należą motywy transakcyjne, finansowe, weryfikacji jakości produktu, korzyści finansowych oraz okoliczności operacyjnych. Motywy dostawcy sprowadzają się natomiast do aspektów marketingowych, dyskryminacji cenowej, ekonomii skali, motywacyjnych, informacyjnych i koordynacyjno-kontrolnych.

Mnogość motywów zarówno po stronie dostawcy, jak i odbiorcy powoduje, że kredyt kupiecki jest głównym źródłem finansowania działalności operacyjnej przedsiębiorstw w Polsce, a jego zaangażowanie w ciągu ostatnich dwudziestu lat nieustannie rosło ${ }^{8}$.

${ }^{4}$ D. Krzemińska, Wiarygodność kontrahenta $w$ kredycie kupieckim, Wydawnictwo Akademii Ekonomicznej w Poznaniu, Poznań 2005, s. 20-23.

${ }^{5}$ Ustawa z 24 kwietnia 1964 r. - Kodeks cywilny, Dz. U. Nr 16, poz. 93 ze zm., art. 353-365.

${ }^{6}$ J. Kubiak, Hierarchia źródet krótkoterminowego finansowania przedsiębiorstwa, Wydawnictwo Akademii Ekonomicznej w Poznaniu, Poznań 2005, s. 33.

${ }^{7}$ D. Zawadzka, Determinanty popytu matych $i$ średnich przedsiębiorstw na kredyt handlowy, Wydawnictwo Uniwersytetu Ekonomicznego w Poznaniu, Poznań 2009, s. 16-17.

${ }^{8}$ Wartość zobowiązań handlowych przedsiębiorstw w Polsce w 1991 r. wynosiła 13 952,0 mln PLN, a w 2012 r. -już 261 216,5 mln PLN, co wskazuje na prawie 19-krotny ich wzrost. Ponadto rośnie udział zobowiązań z tytułu dostaw i usług w ogólnej wartości zobowiązań krótkoterminowych z 42,9\% w 1991 r. aż do $52,2 \%$ w 2012 r. 
Korzystanie z kredytu kupieckiego wiąże się również z występowaniem ryzyka. Wpływa ono na utratę efektywności działania zarówno dostawcy, jak i odbiorcy. Na cele niniejszego opracowania ograniczono się do identyfikacji ryzyka dostawcy jako dawcy kredytu handlowego. Kolejną część artykułu zajmie również charakterystyka metod przeciwdziałania skutkom występowania ryzyka $\mathrm{w}$ transakcjach $\mathrm{z}$ odroczonym terminem płatności.

\section{RYZYKO KREDYTU KUPIECKIEGO I SPOSOBY JEGO OGRANICZENIA}

Udzielanie kredytu handlowego przysparza przedsiębiorstwu korzyści, ale może również powodować wzrost ryzyka związany ze sprzedażą z odroczonym terminem płatności. Występuje ono wówczas, kiedy pojawia się prawdopodobieństwo zaistnienia szkody lub straty. Charakterystycznym elementem ryzyka jest możliwość niepowodzenia w wyniku trudnych do przewidzenia zdarzeń, niezależnych od podmiotu gospodarczego, które prowadzić moga do utraty efektywności jego działania ${ }^{9}$.

Najistotniejszym zagrożeniem towarzyszacym procesowi sprzedaży $\mathrm{z}$ odroczonym terminem płatności jest ry zy k o kredytowe, którego negatywne efekty (takie jak opóźnienie zapłaty lub nawet jej brak) mogą wpływać na utratę płynności przedsiębiorstwa wierzyciela, pogorszenie jego wyników finansowych lub pozycji rynkowej, a w skrajnych wypadkach nawet spowodować upadłość ${ }^{10}$. Istnieje wiele typów ryzyka determinujących powstanie opóźnień płatniczych lub zagrożenie braku płatności. Ze względu na miejsce ich powstawania można wyróżnić zagrożenia zewnętrzne, których realizacja nie jest związana z działalnością przedsiębiorstwa, oraz zagrożenia wewnętrzne, obejmujące przyczyny wynikające bezpośrednio z działalności dłużnika. Do pierwszej grupy zalicza się ryzyko sektora, kraju czy katastroficzne. Grupę zagrożeń wewnętrznych stanowią natomiast ryzyko płynności, wypłacalności, upadłości oraz kontraktowe ${ }^{11}$, których występowanie ma istotny wpływ na moralność płatniczą dłużnika ${ }^{12}$. Motywy braku lub opóźnionej zapłaty są rozmaite. Moga być konsekwencją pogarszającej się sytuacji ekonomiczno-finansowej podmiotu albo sporu kontraktowego, na skutek którego dłużnik ponosi istotną szkodę, a w skrajnych wypadkach - również nieuczciwego działania dłużnika.

Ze względu na możliwość wystąpienia szkody, jaką niesie za sobą realizacja ryzyka, istotne jest podejmowanie przez przedsiębiorcę działań mających na

9 J. Zieleniewski, S. Szczypiorski, Zasady organizacji i techniki handlu zagranicznego, PWE, Warszawa 1961, s. 38, za: R. Blajer, Gwarancje bankowe i ubezpieczeniowe w obrocie miedzynarodowym, Fundacja Rozwoju Rachunkowości w Polsce, Warszawa 1999, s. 1.

${ }^{10}$ P. Rytko, Zarzadzanie kredytem handlowym $w$ matych $i$ średnich przedsiębiorstwach, Difin, Warszawa 2009, s. 37.

11 Ibidem, s. 39.

${ }^{12}$ Mierzona wskaźnikiem Payment Morality Index (PMI), wskazującym na praktyki płatnicze podmiotów gospodarczych. 
celu ochronę jego funkcjonowania przed skutkami nieterminowej płatności lub jej braku. Ogół aktywności zmierzających do minimalizacji lub eliminacji ryzyka nosi miano procesu zarządzania ryzykiem. Stanowi on zespół procedur związanych z identyfikacją, a następnie sterowaniem ryzykiem, czego celem jest przeciwdziałanie jego wystapieniu lub ograniczenie negatywnych skutków w wypadku jego realizacji ${ }^{13}$. Pierwszym etapem procesu jest analiza ryzyka, polegająca na jego identyfikacji, oszacowaniu skali, a następnie ustaleniu hierarchii. Takie podejście umożliwia dobór metod jego kontroli, prowadzących do unikania zagrożenia, ograniczenia ryzyka, minimalizowania skutków, a także jego eliminacji ${ }^{14}$. Innym rozwiązaniem stanowiącym element procesu zarządzana ryzykiem jest jego finansowanie, które polega na zabezpieczeniu finansowym przedsiębiorcy na wypadek wystąpienia trudności ze spływem należności od dłużnika. Przykładem finansowania ryzyka kredytowego jest ub e z pi ec z en i e, którego istota sprowadza się do objęcia ochroną ubezpieczeniową podmiotu gospodarczego na wypadek niewypłacalności dłużnika. Jego transferowy charakter polega na przeniesieniu ciężaru ponoszenia skutków braku zapłaty kontrahenta na towarzystwo ubezpieczeniowe.

Wśród wielu metod zabezpieczenia należności wierzyciela to właśnie ubezpieczenie kredytu kupieckiego zasługuje na uwagę ze względu na jego rosnące zapotrzebowanie w Polsce.

\section{TRANSFER RYZYKA KREDYTOWEGO W TRANSAKCJACH Z ODROCZONYM TERMINEM PŁATNOŚCI}

Ubezpieczenie stanowi zobowiązanie zakładu ubezpieczeń do spełnienia określonego świadczenia $\mathrm{w}$ wypadku wystąpienia zdarzenia przewidzianego umowa ubezpieczenia. Ubezpieczający natomiast zobowiązuje się do zapłaty składki za objęcie jego działalności ochroną ubezpieczeniowa ${ }^{15}$. Analogicznie ubezpieczenie kredytu kupieckiego wynika ze stosunku pomiędzy zakładem ubezpieczeń, zwanym ubezpieczycielem, a ubezpieczającym, w którym pierwszy zobowiązuje się do wypłaty sumy odszkodowania za nieotrzymanie przez ubezpieczającego należności handlowych $\mathrm{z}$ tytułu sprzedaży przez niego towarów i usług z odroczonym terminem płatności. Ubezpieczający zobowiązany jest zaś do poniesienia opłaty składki ubezpieczeniowej ${ }^{16}$. Ubezpieczenie kredytu kupieckiego jest produktem ubezpieczeniowym grupy kredytów towarowych, do której należą również ubezpieczenie sprzedaży ratalnej oraz

\footnotetext{
${ }^{13}$ T. Sangowski (red.), Ubezpieczenia gospodarcze, Poltext, Warszawa 2001, s. 49.

${ }^{14}$ J. Lisowski, Możliwości zabezpieczenia przedsiębiorców przed nastęstwami ryzyka kredytowego, w: T. Saganowski (red.), Studia z ubezpieczen gospodarczych $i$ spotecznych, Zeszyty Naukowe 276, Akademia Ekonomiczna w Poznaniu, Poznań 2000, s. 61.

${ }^{15}$ Art. 805 k.c.

${ }^{16}$ Ogólne warunki ubezpieczenia ryzyka kredytu kupieckiego z opcją windykacji należności 2004 Euler Hermes S.A.
} 
ubezpieczenie leasingu ${ }^{17}$. Charakterystyka ryzyka towarzyszacego kredytowi towarowemu klasyfikuje jego ubezpieczenie do grupy 14 działu II, obejmującego pozostałe ubezpieczenia osobowe oraz ubezpieczenia majątkowe ${ }^{18}$. Ubezpieczającym wierzytelności $\mathrm{z}$ tytułu sprzedaży towarów i usług jest zawsze dostawca, w przeciwieństwie do ubezpieczenia gwarancyjnego, w którym to dłużnik zabezpiecza należności wierzyciela ${ }^{19}$.

Podstawowym aktem zawarcia stosunku pomiędzy ubezpieczającym a zakładem ubezpieczeń jest umowa ubezpieczeniowa oraz ogólne warunki ubezpieczenia. Umowa prezentuje warunki szczegółowe, takie jak: okres jej obowiązywania, maksymalną sumę ubezpieczenia, stawkę składki ubezpieczeniowej, składkę minimalną i warunki jej zapłaty, obrót do ubezpieczenia, parametry oceny ryzyka, a także udział własny ubezpieczającego i wiele innych. Integralną częścią umowy ubezpieczenia są ogólne warunki ubezpieczenia, których celem jest doprecyzowanie warunków określonych w umowie, w tym przede wszystkim zdefiniowanie pojęć, określenie przedmiotu ubezpieczenia, zakresu ochrony ubezpieczeniowej, a także innych praw i obowiązków obu stron. Umowa ma charakter portfelowy, co oznacza, że obejmuje ochrona transakcje z wieloma kontrahentami i nie wymaga aneksowania w wypadku chęci jej rozszerzenia o nowe podmioty ${ }^{20}$.

Zakres ochrony ubezpieczeniowej obejmuje bezsporne należności powstałe w okresie obowiązywania polisy ubezpieczeniowej, których fakt powstania został potwierdzony dokumentami odbioru i faktura. Dotyczy on jedynie transakcji z klientami prowadzącymi działalność gospodarczą, którzy spełnili warunki kontroli towarzystwa ubezpieczeń i na których został przydzielony limit kredytowy. Ochrona ubezpieczeniowa nie obejmuje natomiast należności od podmiotów publiczno-prawnych, wierzytelności od podmiotów dominujących lub zależnych w grupach kapitałowych, a także odsetek, kar, należności celno-podatkowych, czy strat spowodowanych naruszeniem lub niewykonaniem przez ubezpieczającego warunków umowy oraz szkód powstałych w wyniku realizacji ryzyka politycznego ${ }^{21}$.

Ochrona ubezpieczeniowa należności wierzyciela następuje $\mathrm{z}$ chwilą nadania przez ubezpieczyciela limitu kredytowego na transakcje handlowe z kontrahentem. W trakcie trwania polisy ubezpieczyciel może obniżyć lub zredukować do zera limit na przyszłe transakcje z klientem, wobec którego stwierdzono zwiększenie się ryzyka. Takie podejście eliminuje odpowiedzialność towarzystwa ubezpieczeniowego za ryzyko wszystkich transakcji,

${ }_{17}$ J. Kukiełka, Ubezpieczenie kredytu, Centrum Edukacji i Rozwoju Biznesu, Warszawa 1994, s. 29.

18 Zob. http://www.knf.gov.pl.

19 J. Kufel, Ubezpieczenia gospodarcze w orzecznictwie sadowym, Wydawnictwo Branta, Bydgoszcz 2002 , s. 242.

${ }^{20}$ J. Kukiełka, M. Matusiak, J. Jaworski, Bezpieczny obrót gospodarczy, czyli jak ograniczyć ryzyko handlowe $w$ transakcjach krajowych $i$ eksportowych, Polska Agencja Rozwoju Przedsiębiorczości, Warszawa 2008, s. 56.

${ }^{21} \mathrm{Na}$ podstawie warunków dotyczących wyłączenia i ograniczenia ochrony ubezpieczeniowej zawartych w Ogólnych warunkach ubezpieczenia Euler Hermes S.A., KUKE S.A. oraz Compagnie Francaise D'Assurance Pour Le Commerce Exterieur S.A. (Coface). 
które następują po powiadomieniu ubezpieczającego o redukcji limitu ubezpieczeniowego. Przyczynami tego moga być ${ }^{22}$ :

- całkowite lub częściowe zaprzestanie działalności dłużnika lub zmiana jej profilu,

- istotne zmiany prawne, własnościowe bądź związane $\mathrm{z}$ pełnionym zarządem,

- pogorszenie się sytuacji finansowej dłużnika lub podmiotów z nim powiązanych, co stanowi odzwierciedlenie w jego sprawozdaniach finansowych,

- trudności w ocenie sytuacji finansowej dłużnika w związku z nieprzekazywaniem przez niego na czas sprawozdań finansowych,

- zgłoszenie przez dłużnika lub podmiotów z nim powiązanych wniosku o przeprowadzenie postępowania upadłościowego, układowego lub naprawczego,

- pogorszenie moralności płatniczej dłużnika skutkujące powstałymi opóźnieniami płatniczymi względem kontrahentów,

- pozyskanie przez ubezpieczyciela innych informacji wpływających na decyzję o redukcji limitu,

- decyzje ubezpieczyciela względem kraju, w którym podmiot rezyduje, będące konsekwencja pogarszającej się sytuacji ekonomicznej lub politycznej,

- niedopełnienie przez ubezpieczającego warunków formalnych dotyczących sprawozdawczości jego współpracy z dłużnikiem.

Konsekwencja redukcji limitów na kontrahentów może być zachwianie polityki sprzedażowej dostawcy wobec klienta, którą we wcześniejszym okresie determinowała wielkość posiadanego limitu. Każda kolejna sprzedaż do kontrahenta obarczona jest większym ryzykiem, co potwierdza decyzja ubezpieczyciela. Brak ochrony ubezpieczeniowej, spowodowanej obniżeniem lub redukcją limitu dla dłużnika przez ubezpieczyciela, nie oznacza jednak braku możliwości sprzedaży do kontrahenta, którego decyzja dotyczy. To dostawca podejmuje ostateczną decyzję na podstawie swojej własnej oceny ryzyka planowanego przedsięwzięcia, a także stopnia istotności przyszłej transakcji w działalności przedsiębiorstwa. W wyniku powstałych okoliczności może się ono zwrócić do partnera handlowego z propozycją dodatkowego zabezpieczenia sprzedaży lub sprzedać bez zabezpieczenia. Oba rozwiązania mogá przysparzać jednak wielu trudności. Wypracowana bowiem praktyka ubezpieczania należności przez podmioty gospodarcze spowodowała, że możliwości dokonania we własnym zakresie oceny kondycji finansowej kontrahenta sa ograniczone. Z kolei sprzedaż bez zabezpieczenia niesie za sobą możliwość poniesienia straty w wyniku realizacji ryzyka opóźnienia płatności przez dłużnika lub nawet jej braku. Często jednak zdarza się, że obniżenie lub anulowanie limitu ubezpieczeniowego powodują wstrzymanie sprzedaży. Jeśli decyzja ubezpieczyciela dotyczy niewielu podmiotów, nie należy upatrywać się istotności zjawiska dla działalności ubezpieczającego. Determinuje ją przede wszystkim wielkość portfela klientów i ich zamówień. Im bardziej rozdrobniona sprzedaż wierzyciela, tym mniejsze sa skutki decyzji zakładu ubezpieczeń.

${ }^{22}$ Ogólne warunki ubezpieczenia krótkoterminowych należności eksportowych i krajowych (OP) KUKE, $\S 10$, pkt 6 . 
Opisywane zjawisko nabiera znaczenia w okresie pogarszającej się sytuacji ekonomicznej, słabnącej kondycji sektora przedsiębiorstw, ponieważ redukcja lub anulacja limitów dotyczą wielu podmiotów gospodarczych. Wówczas decyzje zakładów ubezpieczeniowych stanowią istotny problem i moga prowadzić do zachwiania działalności przedsiębiorstw zarówno dłużnika, przez odebranie możliwości korzystania z kredytu kupieckiego, jak i wierzyciela, przez ograniczenie jego możliwości sprzedażowych, a także trudności w spływie dotychczasowych należności.

\section{DETERMINANTY PODWYŻSZONEGO RYZYKA W KREDYCIE KUPIECKIM}

Po długim okresie dynamicznego wzrostu gospodarczego w końcu 2008 r. odnotowano w Polsce istotne załamanie podstawowych wskaźników ekonomicznych ${ }^{23}$. U podstaw dekoniunktury leżał globalny kryzys finansowy, którego skutkiem była recesja wielu gospodarek. Pomimo tylko pośredniego wpływu omawianych zjawisk na kondycje polskiego sektora bankowego okres ten charakteryzował się przeszacowaniem ryzyka i zaostrzeniem kryteriów kredytowych, co w znaczący sposób ograniczyło dostęp do kredytów zarówno dla gospodarstw domowych, jak i przedsiębiorstw. Utrata efektywności sektora bankowego spowodowała spadek aktywności w sferze realnej, czego wyrazem było osłabienie popytu oraz produkcji przemysłowej jako elementu działań dostosowujących do nowego otoczenia.

W sektorze przedsiębiorczości pierwsze symptomy dekoniunktury gospodarczej odnotowano już w 2008 r., towarzyszył im spadek zyskowności przy jednoczesnym istotnym wzroście kosztów ze sprzedaży i wzroście zobowiązań ${ }^{24}$. Jedną z przyczyn osłabienia wskaźników płynności finansowej było niedostosowanie działalności do nowych warunków, w tym przede wszystkim w kontekście zapasów, które rosły niewspółmiernie szybko w porównaniu z pozostałymi wskaźnikami oraz kosztami prowadzonej działalności ${ }^{25}$.

Kolejne lata, choć charakteryzowały się wzrostem rentowności przedsiębiorstw, cechowała nadal duża niepewność. Zachowania przedsiębiorstw prezentowały już racjonalne gospodarowanie posiadanymi zasobami, co wskazują wskaźniki dynamiki zobowiązań i zapasu ${ }^{26}$. W 2012 r. zaobserwowano po

${ }^{23}$ Dynamika wzrostu PKB sięgała w 2007 r. 6,8\%, 5,1\% w następnym roku i tylko 1,6\% w 2009 r. Tempo wzrostu konsumpcji również wyraźnie wyhamowało z 6,1\% w 2008 r. do 2,0\% rok później. Obniżeniu uległ popyt krajowy (-1,1\% w 2009 r.) oraz inwestycje (-1,2\% w analogicznym okresie), a także obroty z zagranicą (-12,4\% import, $6,8 \%$ eksport).

${ }^{24}$ Zysk netto przedsiębiorstw w Polsce wynosił w 2008 r. 85323 mln PLN, co stanowi spadek o ponad 10,6\% w porównaniu z 2007 r. Wielkość zobowiązań wzrosła w omawianym okresie o ponad 63679 mln PLN do poziomu 551962 mln PLN, głównie za sprawą zwiększenia zaangażowania kredytu kupieckiego.

${ }^{25} \mathrm{~W} 2008$ r. zapasy przedsiębiorstw wzrosły o blisko $18 \%$, a sprzedaż - o blisko $11 \%$.

${ }^{26}$ W latach 2009-2010 odnotowano znacznie niższą dynamikę wzrostu zobowiązań handlowych: $5,4 \%$ i $6,7 \%$ względem $14,5 \%$ i $11,1 \%$ w okresie dwóch poprzedzających lat. Ponadto wzrost zobowiązań nie powodował istotnego wzrostu zapasu, który niesie za sobą ryzyko związane z osłabieniem płynności. 


\section{Wykres 1}

Postanowienia upadłościowe w Polsce w latach 2007-2013

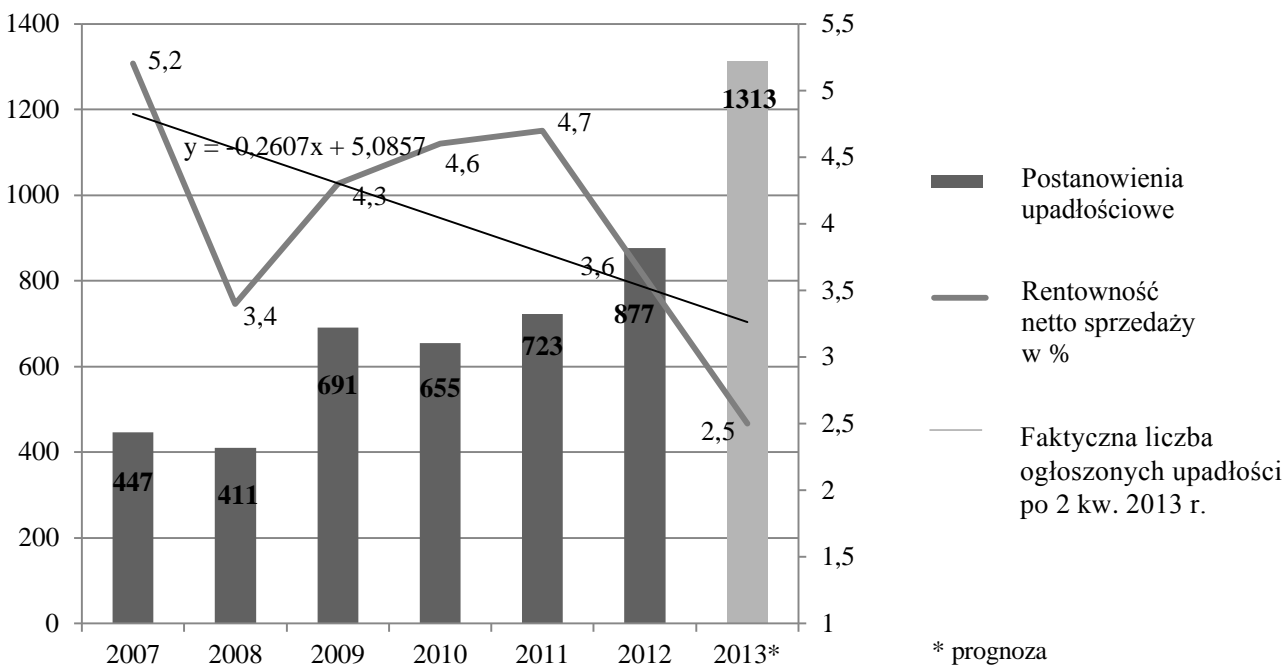

Źródło: dane z raportu Coface na temat upadłości firm w Polsce w 2012 r. oraz komunikatu prasowego KUKE: Upadtości firm w Polsce - prognozy KUKE na rok 2013.

raz kolejny spadek zysku przedsiębiorstw w Polsce o $13 \%$ do poziomu 105437 mln PLN, przy jednoczesnym pogłębianiu się straty nierentownych podmiotów aż o $35,8 \%$ do $23320 \mathrm{mln}$ PLN.

Jednym z najistotniejszych parametrów wskazujących na kondycję sektora przedsiębiorstw jest współczynnik upadłości. Mimo że nie obrazuje on wszystkich zmian zachodzących w zakresie aktywności podmiotów gospodarczych ${ }^{27}$, stanowi podstawę do oceny efektywności działalności przedsiębiorstw. Jest również istotnym czynnikiem determinującym poziom ryzyka prowadzonej działalności, w tym przede wszystkim ryzyka płatności. Wykres 1 prezentuje liczbę postanowień upadłościowych w Polsce w latach 2007-2012 oraz prognozę na 2013 r. na tle wskaźników rentowności sprzedaży.

Począwszy od 2009 r., liczba podmiotów, wobec których sąd wydał postanowienie o upadłości, nieustannie rosła. Omawiany okres charakteryzował się trudnościami w zakresie rentowności sektora przedsiębiorstw, które determinowały wzrostowy trend upadłości.

Wykres 1 prezentuje skalę postępujących negatywnych zmian w sektorze przedsiębiorstw, których wynikiem jest wzrastająca liczba ich upadłości w Polsce. Obserwuje się zależność pomiędzy kierunkiem zmian w zakresie rentowności a liczbą upadłości. Pogorszenie się rentowności ze sprzedaży

${ }^{27}$ Nie wskazuje podmiotów będących w likwidacji czy tych, które czasowo zawiesiły działalność gospodarczą. 


\section{Wykres 2}

Spływ należności względem terminów ich wymagalności w 2008 i 2012 r.

2012

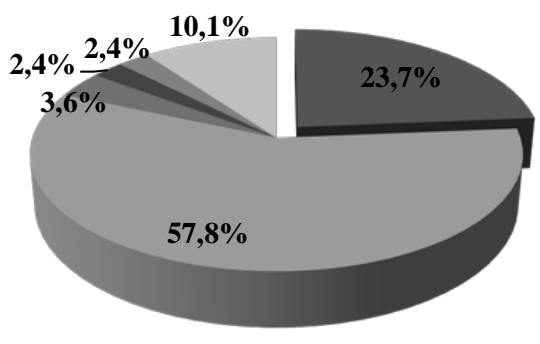

- w terminie $\quad<30 \mathrm{dni} \quad$ 30-60 dni

- 60-90 dni $\quad$ 90-120 dni $\square>120 \mathrm{dni}$
2008

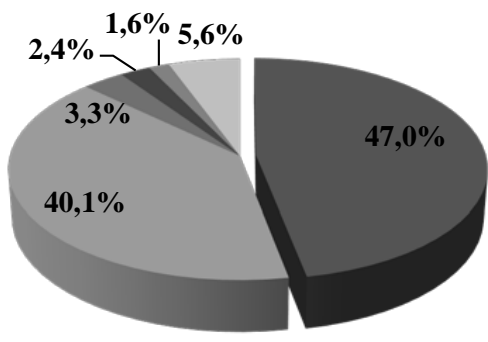

-w terminie $\quad \square<30 \mathrm{dni} \quad \square 30-60 \mathrm{dni}$

घ6-90 dni $\quad 90-120 \mathrm{dni} \quad>120 \mathrm{dni}$

Źródło: „Gazeta Finansowa” na podstawie danych z raportu Dun \& Bradstreet dotyczącego moralności płatniczej.

w 2008 r. skutkowało istotnym wzrostem liczby upadłości już w roku kolejnym. Ponadto w związku ze spadkiem rentowności w 2012 r. oraz prognozą wskaźnika rentowności na poziomie $2,5 \%$ w $2013 \mathrm{r}$. przewiduje się dalszy wzrost liczby bankructw, aż do poziomu 1313 wydanych przez sądy postanowień o ogłoszeniu upadłości ${ }^{28}$.

Innym istotnym parametrem obrazującym efektywność sektora przedsiębiorstw oraz skalę ryzyka płatności jest charakterystyka praktyk płatniczych determinowanych wielkością przeterminowanych wierzytelności. Począwszy od 2008 r., nastąpiło istotne pogorszenie w zakresie terminów regulowania zobowiązań, które spowodowało, że w 2012 r. aż 76,3\% faktur regulowano po terminie ich wymagalności. Wykres 2 przedstawia zwyczaje płatnicze przedsiębiorstw w Polsce w 2012 r. na tle wyników płatniczych z 2008 r.

Wykres 2 wskazuje, że w minionych latach drastycznie wzrósł odsetek faktur niepłaconych w terminie. Największy udział stanowią wierzytelności regulowane do 30 dni po terminie ich wymagalności. Niepokojącym jest również fakt, że o 4,5\% wzrosły należności, których spływ następuje ponad 4 miesiące od terminu ich zapadalności. Pod względem wielkości przedsiębiorstwa najsłabiej płacą duże i średnie podmioty. Wśród tych pierwszych zaledwie 16\% faktur regulowanych jest w terminie. Wśród mikro i małych przedsiębiorstw odnotowano natomiast najwyższy odsetek niezapłaconych wierzytelności w przedziale powyżej 120 dni. Według branż najsłabiej wypadły transport, produkcja przemysłowa, górnictwo i budownictwo.

${ }^{28}$ Upadtości firm $w$ Polsce - prognozy KUKE na rok 2013, komunikat prasowy, Korporacja Ubezpieczeń Kredytów Eksportowych, Warszawa, 10.12.2012. 
Istotnym czynnikiem wskazującym na kondycję płatniczą sektora przedsiębiorstw jest wartość wierzytelności zgłoszonych do windykacji wyspecjalizowanym podmiotom. Już w 1 kwartale 2009 r. wartość wierzytelności zgłoszonych do windykacji siedmiu wyspecjalizowanych podmiotów wskazywała wzrost o ponad $36 \% \mathrm{w}$ porównaniu $\mathrm{z}$ analogicznym okresem poprzedniego roku $^{29}$. Wartość wszystkich niezapłaconych należności handlowych zgłoszonych do zewnętrznej windykacji wyniosła w 2010 r. ponad 3 mld PLN. Szacuje się, że do 2014 r. wartość rynku windykacji w Polsce wzrośnie do 22,2 mld PLN ${ }^{30}$.

Nie mniej istotnym parametrem jest wielkość wierzytelności zgłoszonych do Krajowego Rejestru Długów. W branży budowlanej, uważanej przez wielu za barometr polskiej gospodarki, wartość zgłoszonych do rejestru przeterminowanych wierzytelności wynosiła w połowie 2012 r. 399 mln PLN i dotyczyła 9648 podmiotów, a rok później wartość wzrosła do poziomu ponad 518 mln PLN i sięgała 10694 przedsiębiorstw ${ }^{31}$.

Powyższa charakterystyka wskazuje na pogarszającą się sytuację sektora przedsiębiorstw, którą odzwierciedlają spadek rentowności prowadzonej działalności oraz utrata płynności finansowej. W ocenie ponad $80 \%$ przedsiębiorców nieterminowe regulowanie płatności stanowi poważną przeszkodę $\mathrm{w}$ prowadzeniu działalności gospodarczej w Polsce ${ }^{32}$. Nasilające się negatywne efekty dekoniunktury gospodarczej determinują zatem potrzebę zwiększenia bezpieczeństwa prowadzonej działalności gospodarczej, w tym przede wszystkim ograniczenia ryzyka płatności oraz minimalizacji efektów powstania opóźnień płatniczych lub braku zapłaty ze strony dłużnika. Powyższe wskazuje na potrzebę zabezpieczenia wierzytelności przed ich utratą oraz znacznym opóźnieniem spływu.

Skuteczny w ostatnich latach produkt ubezpieczenia kredytu kupieckiego zaczął jednak tracić na uznaniu przedsiębiorców ze względu na radykalne zmniejszanie ryzyka przez firmy ubezpieczeniowe, co w konsekwencji powodowało liczne redukcje i anulacje limitów ubezpieczeniowych. Działania te spowodowały, że w wypadku wielu podmiotów ubezpieczenie nie mogło stanowić zabezpieczenia wierzytelności dostawcy, zatem było bezzasadne. Ponadto brak utrzymania linii kredytowej zabezpieczonej przez ubezpieczyciela wpływał na trudności w zakresie szybkiego spływu wierzytelności zapadłych. Brakowało bowiem narzędzia jego stymulowania, którym jest realizacja kolejnej dostawy towarów po dokonanej płatności. Takie podejście niosło za sobą określone konsekwencje biznesowe dla działalności nie tylko dla przedsiębiorstw korzystających i dostarczających kredyt kupiecki, lecz także

\footnotetext{
${ }^{29}$ Wartość zgłoszonych wierzytelności handlowych przedsiębiorstw do windykacji Euler Hermes, APS Poland, Casus Finanse, EGF, Lexus oraz Koksztys wynosiła w I kwartale 2009 r. 977,9 mln PLN, podczas gdy w porównywalnym okresie 2008 r. - 717,0 mln PLN.

${ }^{30}$ Dane z raportów firm opublikowane przez Europejską Grupę Finansową dotyczą wszystkich wierzytelności handlowych, również należnych przedsiębiorstwom od klientów indywidualnych.

${ }^{31}$ Komentarz Adama Łąckiego, prezesa zarządu Krajowego Rejestru Długów, do raportu Dun \& Bradstreet dot. moralności płatniczej.

${ }^{32}$ Raport BIG Wskaźnik Bezpieczeństwa Dziatalności gospodarczej, BIG InfoMonitor, Warszawa, czerwiec 2013, na podstawie badania TNS POLSKA na próbie 400 podmiotów, przedstawicieli różnych branż.
} 
samych ubezpieczycieli. To z kolei pozwoliło na opracowanie nieznanego dotąd produktu ubezpieczenia należności podwyższonego ryzyka, który chroni przyszłe wierzytelności od ryzyka braku zapłaty przez kontrahenta.

\section{UBEZPIECZENIE NALEŻNOŚCI PODWYŻSZONEGO RYZYKA}

Ubezpieczenie należności wynikających z transakcji handlowych podwyższonego ryzyka jest odpowiedzia towarzystw ubezpieczenia kredytu kupieckiego na słabnącą koniunkturę i konsekwencje tego zjawiska dla działalności operacyjnej przedsiębiorstw i samych ubezpieczycieli.

Praktyka wykazała, że klasyczny produkt ubezpieczenia ryzyka kredytu kupieckiego stał się narzędziem mało efektywnym z powodu trudności w objęciu ochroną ubezpieczeniową transakcji podwyższonego ryzyka, co uniemożliwiało obsługę znacznego portfela zamówień kontrahentów. Negatywne skutki prowadzonej polityki dla rozwoju produktu ubezpieczenia transakcji handlowych od ryzyka płatności zauważyli czołowi ubezpieczyciele, którzy zaproponowali alternatywne rozwiązanie przedsiębiorcom. Polega ono na udzieleniu dodatkowej ochrony ubezpieczeniowej w wypadku posiadania przez klienta niewystarczającego limitu w ramach podstawowej weryfikacji lub nawet jego całkowitego braku. Ubezpieczający natomiast zobowiązany jest zapłacić dodatkowy koszt za każdy udzielony limit, który jest determinowany wielkością ryzyka, jakie ponosi ubezpieczyciel.

Pierwszym spośród zakładów ubezpieczeń oferującym produkt dodatkowej ochrony ubezpieczeniowej w Polsce był Euler Hermes, który już w połowie 2012 r. dysponował pakietem dodatkowych limitów na klientów podwyższonego ryzyka. Pozostali liczący się ubezpieczyciele szybko zauważyli potrzebę oferowania klientom ponadstandardowej ochrony ubezpieczeniowej. Do połowy 2013 r. omawiany produkt stanowił istotny element oferty handlowej już trzech spośród czterech największych ubezpieczycieli kredytu kupieckiego w Polsce. W tabeli 1 przedstawiono podstawowe parametry produktów ubezpieczenia kredytu kupieckiego w transakcjach podwyższonego ryzyka, oferowanych przez działające na polskim rynku zakłady ubezpieczeń.

Prezentowana analiza porównawcza wskazuje na różnice zarówno w zakresie oferowanej ochrony ubezpieczeniowej, jak i w parametrach szczegółowych, determinujących atrakcyjność ofert ubezpieczycieli. Zarówno Euler Hermes, jak i Coface dysponuja ofertą produktu ubezpieczenia należności wynikajacych $\mathrm{z}$ transakcji handlowych $\mathrm{z}$ klientami nieposiadającymi wystarczającego limitu podstawowego, jak również tymi, którzy nie posiadaja limitu w ogóle. KUKE oferuje natomiast dodatkowe ubezpieczenie należności tylko $\mathrm{w}$ sytuacjach, kiedy limit podstawowy, wynikający ze standardowej weryfikacji, jest niewystarczający. Oferty różnią się maksymalną wartością limitów na pojedynczego klienta. Najwyższe limity dodatkowe, sięgające nawet $20 \mathrm{mln}$ PLN, 
Tabela 1

Porównanie ofert dodatkowej ochrony ubezpieczeniowej

\begin{tabular}{|c|c|c|c|c|}
\hline \multirow{2}{*}{$\begin{array}{c}\text { Parametry } \\
\text { oferty }\end{array}$} & \multicolumn{2}{|c|}{ Euler Hermes } & \multirow{2}{*}{$\begin{array}{c}\text { Coface } \\
\text { TopLiner }\end{array}$} & \multirow{2}{*}{$\begin{array}{c}\text { KUKE } \\
\text { Ochrona }+\end{array}$} \\
\hline & CAP & CAP + & & \\
\hline Forma współpracy & polisa CAP Europe & polisa CAP Europe & $\begin{array}{l}\text { moduł do polisy } \\
\text { podstawowej }\end{array}$ & $\begin{array}{l}\text { wniosek dodatko- } \\
\text { wy limit kredyto- } \\
\text { wy do polisy pod- } \\
\text { stawowej }\end{array}$ \\
\hline $\begin{array}{l}\text { Możliwość } \\
\text { ubiegania się } \\
\text { o limity } \\
\text { dodatkowe }\end{array}$ & $\begin{array}{l}\text { limit podstawowy } \\
\text { jest niewystarcza- } \\
\text { jacy }\end{array}$ & $\begin{array}{l}\text { brak limitu } \\
\text { podstawowego }\end{array}$ & $\begin{array}{l}\text { limit podstawowy } \\
\text { jest niewystarcza- } \\
\text { jący lub brak li- } \\
\text { mitu podstawowe- } \\
\text { go }\end{array}$ & $\begin{array}{l}\text { limit podstawowy } \\
\text { jest niewystarcza- } \\
\text { jący }\end{array}$ \\
\hline $\begin{array}{l}\text { Maksymalna } \\
\text { wartość limitu } \\
\text { na klienta }\end{array}$ & $\begin{array}{l}\text { do } 4000000 \text { PLN, } \\
\text { jednak nie więcej } \\
\text { niż wysokość limitu } \\
\text { podstawowego }\end{array}$ & do 200000 PLN & $20000-20000000$ PLN & do 5000000 PLN \\
\hline $\begin{array}{l}\text { Prawo } \\
\text { ubezpieczyciela } \\
\text { do odmowy limitu }\end{array}$ & tak & tak & tak & tak \\
\hline $\begin{array}{l}\text { Prawo } \\
\text { ubezpieczyciela } \\
\text { do obniżenia } \\
\text { lub anulacji limitu }\end{array}$ & tak & tak & tak & tak \\
\hline Udział własny & $10 \%$ & $10 \%$ & $10 \%$ & $15 \%$ \\
\hline $\begin{array}{l}\text { Składka } \\
\text { ubezpieczeniowa }\end{array}$ & $\begin{array}{l}1 / 12 \text { z } 2 \% \text { wartości } \\
\text { limitu CAP } \\
\text { dotyczącego danego } \\
\text { klienta w miesiącu }\end{array}$ & $\begin{array}{l}\text { 1/12 z } 4 \% \text { wartości } \\
\text { limitu CAP }+ \\
\text { dotyczącego danego } \\
\text { klienta w miesiącu }\end{array}$ & $\begin{array}{l}\text { 0,2-0,6\% wartości } \\
\text { przyznanego limitu } \\
\text { dodatkowego na } \\
\text { klienta za każdy } \\
\text { miesiąc }\end{array}$ & $\begin{array}{l}0,5 \% \text { kwoty limitu } \\
\text { dodatkowego na } \\
\text { klienta za okres } \\
3 \text { miesięcy }\end{array}$ \\
\hline $\begin{array}{l}\text { Roczna składka } \\
\text { minimalna } \\
\text { dla produktu } \\
\text { dodatkowej } \\
\text { ochrony }\end{array}$ & jest & jest & $\begin{array}{l}\text { tylko dla polisy } \\
\text { podstawowej }\end{array}$ & $\begin{array}{l}\text { tylko dla polisy } \\
\text { podstawowej }\end{array}$ \\
\hline $\begin{array}{l}\text { Opłaty za ocenę } \\
\text { ryzyka }\end{array}$ & $\begin{array}{l}200 \text { PLN za każdy } \\
\text { limit }\end{array}$ & $\begin{array}{l}200 \text { PLN za każdy } \\
\text { limit }\end{array}$ & $\begin{array}{l}230 \text { PLN za każdy } \\
\text { limit }\end{array}$ & $\begin{array}{l}170 \text { PLN za każdy } \\
\text { limit, } 100 \text { PLN } \\
\text { za limit „,0" PLN }\end{array}$ \\
\hline $\begin{array}{l}\text { Płatność składki } \\
\text { ubezpieczeniowej }\end{array}$ & $\begin{array}{l}\text { za każdy miesiąc, } \\
\text { jako suma składek } \\
\text { za poszczególne } \\
\text { limity dodatkowe }\end{array}$ & \begin{tabular}{|l} 
za każdy miesiąc, \\
jako suma składek \\
za poszczególne \\
limity dodatkowe
\end{tabular} & $\begin{array}{l}\text { jednorazowo na } \\
\text { podstawie } \\
\text { wystawionego } \\
\text { rachunku }\end{array}$ & $\begin{array}{l}\text { jednorazowo na } \\
\text { podstawie } \\
\text { wystawionego } \\
\text { rachunku }\end{array}$ \\
\hline
\end{tabular}


cd. tab. 1

\begin{tabular}{|c|c|c|c|c|}
\hline $\begin{array}{l}\text { Maksymalna } \\
\text { wysokość } \\
\text { odszkodowania }\end{array}$ & $\begin{array}{l}\text { określona } \\
\text { wielokrotnością } \\
\text { zapłaconej składki } \\
\text { polisy dodatkowej } \\
\text { za rok } \\
\text { ubezpieczeniowy }\end{array}$ & $\begin{array}{l}\text { określona } \\
\text { wielokrotnością } \\
\text { zapłaconej składki } \\
\text { polisy dodatkowej } \\
\text { za rok } \\
\text { ubezpieczeniowy }\end{array}$ & $\begin{array}{l}\text { określona } \\
\text { wielokrotnościa } \\
\text { zapłaconej składki } \\
\text { polisy podstawowej } \\
\text { za rok } \\
\text { ubezpieczeniowy }\end{array}$ & $\begin{array}{l}\text { określona } \\
\text { wielokrotnością } \\
\text { zapłaconej składki } \\
\text { polisy podstawowej } \\
\text { za rok } \\
\text { ubezpieczeniowy }\end{array}$ \\
\hline $\begin{array}{l}\text { Okres trwania } \\
\text { umowy }\end{array}$ & $\begin{array}{l}\text { po zawarciu } \\
\text { umowy CAP } \\
\text { Europe i złożeniu } \\
\text { pierwszego } \\
\text { wniosku o limit } \\
\text { dodatkowy do } \\
\text { końca } \\
\text { obowiazzywania } \\
\text { umowy } \\
\text { podstawowej }\end{array}$ & $\begin{array}{l}\text { po zawarciu } \\
\text { umowy CAP } \\
\text { Europe i złożeniu } \\
\text { pierwszego } \\
\text { wniosku o limit } \\
\text { dodatkowy do } \\
\text { końca } \\
\text { obowiązywania } \\
\text { umowy } \\
\text { podstawowej }\end{array}$ & $\begin{array}{l}30-90 \text { dni od daty } \\
\text { zawiadomienia } \\
\text { o udzieleniu limitu } \\
\text { dodatkowego do } \\
\text { wygaśnięcia limitu } \\
\text { lub pojawienia się } \\
\text { okoliczności } \\
\text { niewypłacalności } \\
\text { dłużnika }\end{array}$ & $\begin{array}{l}\text { na okres do } 90 \text { dni } \\
\text { od daty } \\
\text { potwierdzenia } \\
\text { udzielenia limitu } \\
\text { do końca terminu } \\
\text { obowiązywania } \\
\text { określonego przez } \\
\text { ubezpieczyciela }\end{array}$ \\
\hline
\end{tabular}

Źródło: Ogólne warunki ubezpieczenia dla polisy CAP Europe, Ogólne warunki ubezpieczenia polisy Globalliance oraz szczegółowe warunki modułu ryzyko, Ogólne warunki ubezpieczenia krótkoterminowych należności eksportowych i krajowych (OP), oferty handlowe ubezpieczycieli.

proponuje Coface. Z analizy wynika jednak, że produkt, który oferuje, jest najdroższy spośród wszystkich zaprezentowanych w niniejszym opracowaniu. Jego cena sięga nawet $0,6 \%$ wartości przyznanego limitu dodatkowego za każdy miesiąc jego obowiązywania, podczas gdy CAP + oferowany przez Euler Hermes kosztuje $0,34 \%$ miesięcznie od wartości dodatkowego limitu ${ }^{33}$. Innym istotnym parametrem oferty jest wielkość udziału własnego ubezpieczającego. Zarówno Euler Hermes, jak i Coface określaja ją na poziomie $10 \%$, natomiast KUKE $-15 \%$. Wszyscy ubezpieczyciele pozostawiaja sobie prawo do odmowy udzielenia limitu dodatkowego lub jego obniżenia, a także anulacji w sytuacjach, kiedy poziom ryzyka jest bardzo wysoki, zazwyczaj określony jako upadłość lub niewypłacalność kontrahenta. Niebagatelną determinantą atrakcyjności produktu jest szybkość i łatwość jego pozyskania. Euler Hermes oczekuje, aby możliwość korzystania z pakietu limitów dodatkowych następowała po podpisaniu dodatkowej polisy ubezpieczenia CAP Europe. Pozostali ubezpieczyciele udostępniają produkt jako jeden z modułów polisy podstawowej lub w formie wniosku o dodatkowy limit kredytowy. Innymi czynnikami wpływającymi na elastyczność ubezpieczenia są okres trwania limitów, roczna składka minimalna czy sposób regulowania płatności składek. Coface oferuje limity

${ }^{33}$ Analiza atrakcyjności oferty ubezpieczycieli pod względem ceny produktów ubezpieczenia podwyższonego ryzyka przysparza wielu trudności, ponieważ w każdym wypadku może być ona inna. Koszt limitu dodatkowego determinowany jest wielkością ryzyka potencjalnych transakcji, a może być ono różnie rozumiane przez poszczególnych ubezpieczycieli. Ponadto ze względu na fakt, że ubezpieczenie należności jest produktem oferowanym wyłącznie w obrocie profesjonalnym, ubezpieczyciele niechętnie publikuja informacje na temat jego ceny. Zebrany materiał pochodził z dostępnych źródeł towarzystw ubezpieczeniowych, jak również wywiadów z przedstawicielami ubezpieczycieli. 
w przedziale od 30 do 90 dni, KUKE - na 90 dni, a Euler Hermes wykazuje $\mathrm{w}$ tym aspekcie pełną dowolność, ponieważ limity trwają w całym okresie obowiązywania polisy, zatem może to być nawet 1 rok. Roczna składka minimalna natomiast dotyczy tylko polisy CAP Europe. Pozostali ubezpieczyciele nakładaja obowiązek uiszczenia składki minimalnej tylko w odniesieniu do polis podstawowych. Wygodny sposób regulowania opłat za limity dodatkowe proponuje Euler Hermes, który rozlicza się z klientami w formie miesięcznych opłat. Coface i KUKE oczekuja płatności na podstawie rachunków wystawianych z góry za każdy limit.

Analiza porównawcza przybliża ofertę produktową poszczególnych ubezpieczycieli dotycząca zabezpieczenia dodatkowego ryzyka w kredycie kupieckim. Wskazuje na poszczególne jej parametry - określa w ten sposób stopień atrakcyjności produktu. Trudno jest jednoznacznie określić, który z ubezpieczycieli prezentuje najkorzystniejszą ofertę. Ubezpieczenie podwyższonego ryzyka kredytu kupieckiego jest bowiem produktem dedykowanym, co oznacza, że można je rozpatrywać wyłącznie w odniesieniu do danego podmiotu i jego otoczenia. Skuteczne ubezpieczenie winno być dobrze dopasowane do oczekiwań klienta, zatem niektóre spośród parametrów oferty na pozór mało istotne dla jednego kontrahenta mogą okazać się kluczowe dla innego.

Reasumując, można stwierdzić, że ubezpieczenie podwyższonego ryzyka w kredycie kupieckim to innowacyjny i atrakcyjny produkt na okres dekoniunktury gospodarczej. Pozwala na uzyskanie korzyści biznesowych przedsiębiorstwom dostarczającym krótkoterminowego finansowania handlowego innym podmiotom oraz tym, które absorbuja kredyt kupiecki. Ubezpieczający zachowują bezpieczeństwo działalności, a jednocześnie nie ograniczają swojej sprzedaży. Ponadto dzięki ubezpieczeniu sprzedający moga korzystać z takich dodatkowych instrumentów stymulujących spływ należności, jak faktoring, który w wielu wypadkach wymaga ochrony ubezpieczeniowej wierzytelności. Kupujący natomiast zyskują dostęp do źródła finansowania. Podstawową wadą natomiast dodatkowego ubezpieczenia jest jego koszt. W zależności jednak od uwarunkowań, w jakich funkcjonują podmioty i relacji pomiędzy nimi, istnieje możliwość rozważenia podziału kosztów związanych z ubezpieczeniem. Innym aspektem jest maksymalne wykorzystanie dostępnego kredytu, co wpływa na ograniczenie kosztów finansowania, a jednocześnie skłania dłużnika do zapłaty w wyznaczonym terminie.

Dodatkowe ubezpieczenie jest również jednym ze sposobów ubezpieczycieli na dalszy rozwój ubezpieczenia należności na polskim rynku i wzrostu własnych przychodów z pobieranych składek. Bez wątpienia produkt ubezpieczenia należności podwyższonego ryzyka znacznie umacnia rolę ubezpieczenia kredytu kupieckiego w Polsce.

\section{PODSUMOWANIE}

Niniejsze opracowanie prezentuje charakterystykę zmian na rynku ubezpieczenia kredytu kupieckiego umożliwiających uzyskanie ochrony ubezpieczeniowej należności o podwyższonym ryzyku. W wyniku słabnącej koniunktury na 
rynku polskim oraz spadku efektywności sektora przedsiębiorstw zahamowany został rozwój klasycznego ubezpieczenia kredytu kupieckiego. Bariery związane z redukcją lub anulacją limitów kredytowych na transakcje handlowe przez ubezpieczycieli spowodowały spadek zainteresowania ta forma zabezpieczenia należności z tytułu dostaw towarów i usług. Odpowiedzią ubezpieczycieli na zaistniała sytuację było rozszerzenie swojej oferty produktowej o ubezpieczenie należności podwyższonego ryzyka.

Postępujący kierunek zmian należy ocenić pozytywnie, ponieważ zalety związane z nowymi rozwiązaniami wpływać mogą na poprawę efektywności przedsiębiorstw i samych ubezpieczycieli i jednocześnie podnieść znaczenie ubezpieczenia należności w Polsce.

Artykuł nakreśla istotę zmian w zakresie ubezpieczenia kredytu kupieckiego w Polsce i podkreśla jego znaczenie dla efektywności prowadzonej działalności przedsiębiorstw. Aktualność prezentowanych zjawisk daje podstawę do dalszych badań, zgłębiających problematykę ubezpieczenia należności o podwyższonym ryzyku i jego znaczenia dla działalności przedsiębiorstw i towarzystw ubezpieczenia kredytu kupieckiego.

mgr Adrian Becella

Uniwersytet Ekonomiczny w Poznaniu

adrian.becella@interia.pl

\section{SIGNIFICANCE OF A CREDIT LIMIT AND TRADE CREDIT INSURANCE IN POLAND}

\section{Summary}

This study indicates the nature of changes in trade credit insurance in Poland. These changes have been caused by sudden deterioration in the macroeconomic situation in Poland, which, after 2008, led to the decrease in the effectiveness of businesses, including trade credit insurance companies. This study is a review of issues concerning trade credit, risk, and ways of reducing it. The significance of trade credit insurance as an effective tool of securing receivables is emphasised, but this is followed by a discussion of the disadvantages of using a classical trade credit insurance in the period of recession or a weak market, which makes insurance companies reduce the risk by reducing insurance limits, making the product ineffective. The result of this is a decrease in effectiveness of both, the insurance companies as well as the users of trade credit insurance. Therefore, insurers are now offering a new product called a high-risk trade credit insurance.

This new insurance product satisfies clients' expectations and constitutes a very good basis for further development of the insurance market in Poland. It not only allows the creditor to develop sales in safe conditions, and the debtor to benefit from a constant access to the capital in the form of a trade credit, but also stimulates sales of additional insurance products, thus generating extra income for insurance companies. In short, it is beneficial to all the actors on the insurance market.

To sum up, in the author's opinion, high-risk trade credit insurance is an excellent solution which insurance companies have developed in response to the deteriorating economic situation, and it may considerably increase the role of trade credit insurance in Poland. 